\title{
Compilation of the Dakota Aquifer Project Isotope Data and Publications: The Isotope Hydrology Program of the Isotope Sciences Division
}

\author{
M. L. Davisson ${ }^{1}$ \\ D. K. Smith ${ }^{1}$ \\ P. A. Macfarlane ${ }^{2}$ \\ D.O. Whittemore ${ }^{2}$ \\ G.B. Hudson ${ }^{1}$ \\ S. Niemeyer ${ }^{1}$ \\ ${ }^{1}$ Isotope Geochemistry Section, \\ Lawrence Livermore National Laboratory \\ ${ }^{2}$ Kansas Geological Survey, \\ Lawrence Kansas
}

January 1995

This ts an informal report intended primarily for internal or limited external distribution. The opinions and conclusions stated are those of the author and may or may not be those of the Laboratory.

Work performed under the auspices of the U.S. Department of Energy by the

Lawrence Livermore National Laboratory under Contract W-7405-Eng-48. 


\section{DISCLAIMER}

This document was prepared as an account of work sponsored by an agency of the United States Government. Neither the United States Government nor the University of California nor any of their employees, makes any warranty, express or implied, or assumes any legal liability or responsibility for the accuracy, completeness, or usefulness of any information, apparatus, product, or process disclosed, or represents that its use would not infringe privately owned rights. Reference herein to any specific commercial products, process, or service by trade name, trademark, manufacturer, or otherwise, does not necessarily constitute or imply its endorsement, recommendation, or favoring by the United States Government or the University of California. The views and opinions of authors expressed herein do not necessarily state or reflect those of the United States Government or the University of California, and shall not be used for advertising or product endorsement purposes.

This report has been reproduced directly from the best available copy.

Available to DOE and DOE contractors from the

Office of Scientific and Technical Information

P.O. Box 62, Oak Ridge, TN 37831

Prices available from (615) 576-8401, FTS 626-8401

A vailable to the public from the

National Technical Information Service

U.S. Department of Commerce

5285 Port Royal Rd.,

Springfield, VA 22161 


\section{DISCLAIMER}

Portions of this document may be illegible in electronic image products. Images are produced from the best available original document. 
The Isotope Geochemistry Section (IGS) of the Isotope Sciences Division of Lawrence Livermore Laboratory (LLNL) has developed a research program in isotope hydrology over the past several years that initially has focused on subsurface characterization of groundwater resources, but today incorporates surface water, ocean sciences, and coastal processes. With internal research funding that was available in the past, collaborative research projects were developed and sponsored by IGS with several agencies external to the DOE in order to demonstrate the isotope techniques available at LLNL and to become familiar with mainstream issues in isotope hydrology research and water resource development.

In FY92 the then Nuclear Chemistry Division embarked on a scientific collaboration with the Kansas Geological Survey (KGS) to characterize with isotope techniques groundwater of the Dakota Formation of Kansas. The Dakota Formation is a Cretaceous-aged marine sandstone hosting potable groundwater in most regions of Kansas whose use will serve to partially offset the severe overdraft problems in the overlying Ogallala Formation. The isotope characterization of the Dakota groundwater has generated data that delineates sources, ages, and subsurface controls on the water quality. Data generated include $\delta^{18} \mathrm{O}, \delta \mathrm{D},{ }^{3} \mathrm{H},{ }^{14} \mathrm{C},{ }^{13} \mathrm{C},{ }^{36} \mathrm{Cl},{ }^{87} \mathrm{Sr} /{ }^{86} \mathrm{Sr}$, trace elements, and noble gas concentrations. The $\delta^{18} \mathrm{O}, \delta \mathrm{D},{ }^{3} \mathrm{H},{ }^{14} \mathrm{C},{ }^{13} \mathrm{C}$, and ${ }^{36} \mathrm{Cl}$, results are listed in Table 1. Initial interpretations of the data have been published in abstract volumes of 1) the 1993 Geological Society of America National Meeting, 2) the 8th International Conference on Geochronology, Cosmochronology and Isotope Geology, and 3) the 1994 Dakota Aquifer Workshop and Clinic. Copies of all abstracts are included in this brief review. Two manuscripts for peer review literature are currently in progress at LLNL whose authors include IGS and KGS scientists. One report will focus on the sources and ages of the groundwater, and the other will focus on the subsurface controls on the natural water quality. 
Table 1: Dakota Groundwater Results

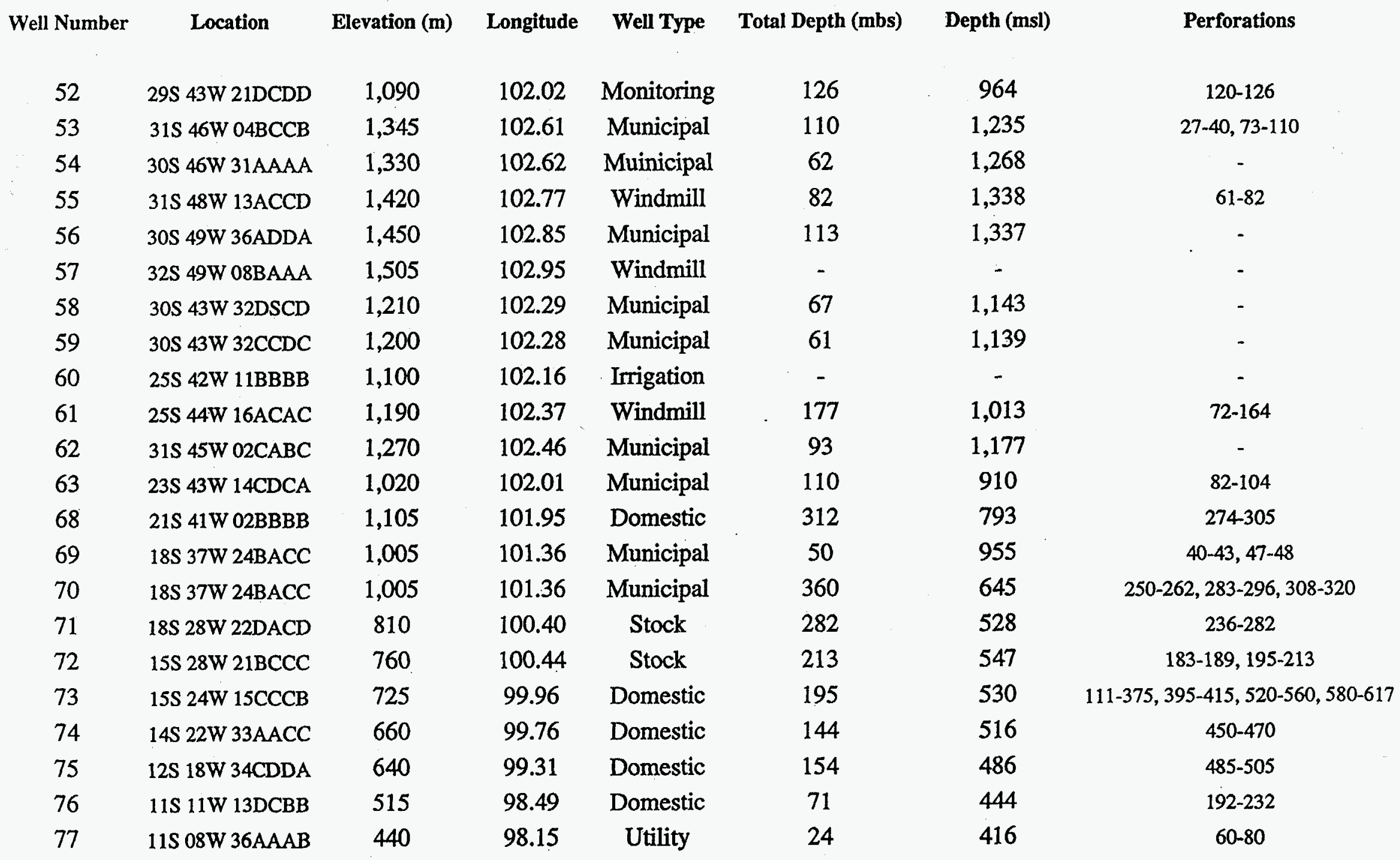


Table 1: Dakota Groundwater Results

\begin{tabular}{|c|c|c|c|c|c|c|c|c|}
\hline Well Number & ${ }^{36} \mathrm{C} / \mathrm{Cl} \times 10^{-14}$ & ${ }^{36} \mathrm{Cl}$ atoms $/ \mathrm{L}$ & ${ }^{14} \mathrm{C}$ pme & $\begin{array}{l}\text { Apparent } \\
{ }^{14} \mathrm{C} \text { Age }\end{array}$ & $\delta^{13} \mathrm{C}$ & ${ }^{3} \mathrm{H}$ TU & $\delta^{18} \mathrm{O}$ & $\delta \mathbf{D}$ \\
\hline 52 & 100.5 & 35 & 17.9 & 14,218 & -6.6 & 2.0 & -10.9 & -79 \\
\hline 53 & 123.1 & 52 & 81.1 & 1,736 & -3.0 & 5.0 & -11.4 & -85 \\
\hline 54 & 150.6 & 52 & 74.4 & 2,440 & -5.4 & 5.8 & -10.7 & -75 \\
\hline 55 & 118.9 & 48 & 27.8 & 10,586 & -4.9 & 0.7 & -14.1 & -103.5 \\
\hline 56 & 110.2 & 5 & 40.6 & 7,458 & -5.7 & 0.1 & -11.5 & -80 \\
\hline 57 & 97.7 & 13 & 75.0 & 2,383 & -5.2 & 0.9 & -9.8 & -67 \\
\hline 58 & 111.0 & 93 & 72.4 & 2,676 & -7.4 & 1.1 & -9.4 & -68 \\
\hline 59 & 110.2 & .42 & 68.2 & 3,163 & -6.2 & 4.0 & -9.7 & -66 \\
\hline 60 & 107.5 & 14 & 37.5 & 8,106 & -7.7 & 0.4 & -9.2 & -60 \\
\hline 61 & 115.6 & 18 & 44.6 & 6,679 & -8.6 & 0.1 & -10.0 & -69 \\
\hline 62 & 107.5 & 10 & 21.6 & 12,684 & -6.3 & - & -12.2 & -88 \\
\hline 63 & 129.1 & 26 & 35.7 & 8,506 & -4.5 & 0.0 & -13.0 & -93 \\
\hline 68 & 47.8 & 13 & 1.2 & 31,330 & -9.0 & 1.4 & -13.2 & -99 \\
\hline 69 & 86.3 & 45 & 70.9 & 2,838 & -8.1 & 4.1 & -8.9 & -61 \\
\hline 70 & 37.9 & 41 & 0.5 & 40,000 & -8.4 & 0.6 & -12.1 & -90 \\
\hline 71 & 19.5 & 99 & 14.9 & 15,750 & -5.1 & 1.1 & -12.5 & -95 \\
\hline 72 & 11.6 & 33 & 5.6 & $23 ; 888$ & -6.4 & 0.9 & -11.8 & -97 \\
\hline 73 & 5.9 & 28 & 0.2 & 40,000 & -4.1 & 0.0 & -12.0 & -87 \\
\hline 74 & 3.2 & 20 & 1.3 & 36,030 & -6.5 & 0.9 & -11.9 & -88 \\
\hline 75 & 0.1 & 3 & 1.7 & 33,831 & -7.3 & 0.3 & -11.7 & -88 \\
\hline 76 & 9.4 & 16 & 18.8 & 13,834 & -8.0 & 5.7. & -9.3 & -64 \\
\hline 77 & 53.3 & 53 & 80.0 & 1,850 & -8.0 & 3.8 & -8.5 & -61 \\
\hline
\end{tabular}


ISOTOPIC INDICATIONS OF AGE AND FLOW CHARACTERISTICS OF GROUNDWATER IN THE DAKOTA AQUTFER, EASTERN COLORADO THROUGH CENTRAL KANSAS.

DAVISSON, M.L. and SMITH, D.K., Lawrence Livermore Laboratory;

MACFARLANE, P.A. and WHITTEMORE, D.O., Kansas Geological Survey;

HUDSON, G.B. and CAFFEE, M., Lawrence Livermore Lab

New data for groundwater from the Dakota aquifer of the central Great Plains region indicates that apparent ${ }^{14} \mathrm{C}$ ages range from $\sim 1800$ to $>40,000$ years at depths from $\sim 15$ to 300 meters below the surface. Systematic "dead" carbonate dissolution into the groundwater probably attenuates the actual age range. The apparent age increase is consistent with the decrease in dissolved $\mathrm{Ca}+\mathrm{Mg}$ from cation exchange for $\mathrm{Na}$ in the confined aquifer. Waters with apparent ages $>10,000$ years appear chemically reduced as indicated by increased dissolved $\mathrm{NH}_{4}$. Lowlevel tritium measurements indicate that some of the young apparent ${ }^{14} \mathrm{C}$ ages $(<10,000$ years) may result from mixing of young shallow groundwater that migrates downward through the gravel pack of the wells.

${ }^{36} \mathrm{Cl} / \mathrm{Cl}$ ratios vary $>3$ orders of magnitude in the Dakota groundwaters. Southeastern Colorado groundwater has ${ }^{36} \mathrm{Cl} / \mathrm{Cl}$ ratios from 980 to $1500 \times 10^{-15}$, while western and central Kansas groundwater shows a marked increase in chloride concentration from 17 to $1400 \mathrm{mg} / \mathrm{L}$ with a corresponding decrease in the ${ }^{36} \mathrm{Cl} / \mathrm{Cl}$ ratio (down to $1.4 \times 10^{-15}$ ). Chloride increases are attributable to upward migration of dissolved halite derived from Permian units stratigraphically below the Dakota and remnant formation water within the Dakota. The $\mathrm{HCO}_{3}$ has a better correlation with the $36 \mathrm{Cl} / \mathrm{Cl}$ ratios $(\mathrm{R}=0.87)$ than with the $\mathrm{Cl}$ alone $(\mathrm{R}=0.43)$.

Dakota groundwater $\delta^{18} \mathrm{O}$ values vary from approx. -8.0 to $-14.0 \%$. The oldest apparent ${ }^{14} \mathrm{C}$ aged groundwater is around $-12.0 \%$ and is limited to a confined zone northeast of the Arkansas River. Younger groundwater that ranges from -8.0 to $-10.0 \%$ may be related to areas dominated by local flow systems. Groundwater around $-14.0 \%$ has an apparent age $\sim 10,000$ years and is located in eastern Colorado and may be related to an intermediate-scale flow system that is recharged at higher elevations to the southwest. The systematic isotopic variations are consistent with model predictions. (MacFarlane, 1993) that the Dakota is dominated by local flow systems in southeastern Colorado and is separate from the intermediate-scale flow system that is located northeast of the Arkansas River in western and central Kansas.

Funding for this work was performed under the auspices of the U.S. DOE by LLNL under contract No. W7405-Eng-48.

Published in Geological Society of America, Abstracts with Programs, 1993 Annual Meeting, Boston, Massachusetts, 1993, vol. 25, no. 6, p. A-375. 
Published in Geological Society of America, Abstracts with Programs, 1993 Annual Meeting, Boston, Massachusetts, 1993, vol. 25, no. 6, p. A-375.

ISOTOPIC, MAJOR AND TRACE ELEMENT SYSTEMATICS OF FLOWSYSTEMS WITHIN THE DAKOTA AQUIFER, COLORADO THROUGH KANSAS

SMITH, D.K., DAVISSON, M.L., VOLPE, A.M., Nuclear Chemistry

Division, L-231, P.O. Box 808, Lawrence Livermore National Laboratory, Livermore, CA 94550; WHITTEMORE, D.O., MACFARLANE, P. A., Kansas Geological Survey, Lawrence, KS 66047; NIEMEYER, S., KENNEALLY, J.M., ESSER, B.K., Lawrence Livermore National Laboratory

Isotopic and elemental analysis of groundwater collected from 20 supply wells along a $500 \mathrm{~km}$ transect of the Dakota aquifer from southeastern Colorado to central Kansas indicates a systematic modification of groundwater chemistry controlled by the flow-system hierarchy. Young ( $\leq 10,000$ year apparent age) oxidized water associated with an unconfined portion of the aquifer southwest of the Arkansas River is relatively enriched in ${ }^{87} \mathrm{Sr} /{ }^{86} \mathrm{Sr}(0.7094-0.7088)$. $\mathrm{U}(7-25 \mu \mathrm{g} / \mathrm{L}), \mathrm{Cr}(0.01-$ $0.3 \mu \mathrm{g} / \mathrm{L}), \mathrm{Rb} / \mathrm{Sr}(0.4-0.7), \mathrm{SiO}_{2}(15-20 \mathrm{mg} / \mathrm{L})$ and ${ }^{36} \mathrm{Cl} / \mathrm{Cl}\left(100-150 \mathrm{E}^{-14}\right)$. Northeast of the Arkansas River, older and chemically more reduced waters (15,000-40,000 year apparent age) are associated with a confined portion of the Dakota aquifer; these waters are relatively enriched in $\mathrm{B}(0.5-1.5 \mathrm{mg} / \mathrm{L}), \mathrm{HCO}_{3}$ (300-550 $\mathrm{mg} / \mathrm{L}), \mathrm{F}(2-5 \mathrm{mg} / \mathrm{L}), \mathrm{NH}_{4}(0.5-1.8 \mathrm{mg} / \mathrm{L})$ and $\mathrm{Cl}^{-}(17-1400 \mathrm{mg} / \mathrm{L})$ and are depleted in radiogenic $\mathrm{Sr}(60-500 \mu \mathrm{g} / \mathrm{L})\left({ }^{87} \mathrm{Sr} / 86 \mathrm{Sr}: 0.7080-0.7086\right)$ and ${ }^{36} \mathrm{Cl} / \mathrm{Cl}\left(0.1-80 \mathrm{E}^{-14}\right)$.

We interpret the differences in isotopic, major and trace element chemistry to the existence of two interconnected, but unique, flow-system types. Southwest of the Arkansas River, localized flow-systems dominate the unconfined recharge area. Northeast of the Arkansas River, a confined flow-system is laterally recharged by water from the southwest which flows beneath the Arkansas River Valley. In the western recharge area, local groundwater acquires $\mathrm{SiO}_{2}, \mathrm{Rb}$ and ${ }^{87} \mathrm{Sr}$. To the northeast, lower ${ }^{87} \mathrm{Sr} / 86 \mathrm{Sr}$ ratios and higher $\mathrm{Cl} / \mathrm{Br}$ ratios $(1700-8500)$ are indicative of deeper Permian saltwaters that migrate upwards by diffusion and discharge into the base of the Dakota aquifer. Further east, young ( $\leq 10,000$ year apparent age) oxidized meteoric waters dilute the saline fluids.

Work performed under the auspices of the U.S. Department of Energy by the Lawrence Livermore National Laboratory under Contract W-7405-Eng-48. 


\title{
Isotopic Indications of Groundwater Sources and Flow in the Dakota Aquifer
}

\author{
M.L. Davisson ${ }^{1}$, D.K. Smith ${ }^{1}$, P.A. Macfarlane ${ }^{2}$, D.O. Whittemore ${ }^{2}$, \\ G.B. Hudson ${ }^{1}$, S. Niemeyer ${ }^{1}$ \\ ${ }^{1}$ Nuclear Chemistry Division, Lawrence Livermore National Laboratory \\ ${ }^{2}$ Kansas Geological Survey, Lawrence Kansas
}

In 1992 the Nuclear Chemistry Division at Lawrence Livermore National Laboratory embarked on a collaborative research project with the Kansas Geological Survey to investigate regional groundwater in the Dakota along an $\sim 450 \mathrm{~km}$ transect from southeastern Colorado through central Kansas using isotopic techniques developed to characterize the age, sources, and flow of groundwater.

Twenty Dakota groundwater samples analyzed show a general bimodal distribution of ${ }^{14} \mathrm{C}$ concentrations, where approximately one-third of the samples range between $60-80$ percent modern carbon (pmc). The remaining samples all fall below 50 pmc with approximately half of those $\leq 2$ pmc. The data indicate that the apparent ${ }^{14} \mathrm{C}$ ages of groundwater range from $\sim 1800$ to $>40,000$ years that increases from depths of $\sim 25$ to 350 meters below the surface (Fig. 1). In general, the greater depths reflect greater distances along various flowpaths. The $\delta^{13} \mathrm{C}$ values for dissolved inorganic carbon in the Dakota aquifer range between -9.0 to $-3.0 \%$. The highest $\delta^{13} \mathrm{C}$ values occur in the western part of the transect and are associated with the younger apparent ${ }^{14} \mathrm{C}$ ages, where, in contrast, the central to eastern part of the transect the higher $\delta^{13} \mathrm{C}$ values are associated with older apparent ${ }^{14} \mathrm{C}$ ages. Addition of dead carbon and attenuation of the ${ }^{14} \mathrm{C}$ ages is increasingly prevalent in areas of greater groundwater confinement, where oxidation of organic matter and calcite dissolution concomitant with ionic exchange reactions influence the total dissolved inorganic carbon. Waters with apparent ages $>10,000$ years appear chemically reduced as indicated by increased dissolved $\mathrm{NH}_{4}$ (Fig. 1). Some of the groundwater samples have measurable tritium levels even though the apparent ${ }^{14} \mathrm{C}$ ages are 1000 's of years old. This suggests that young shallow groundwater probably migrates downward through the gravel pack of the wells and mixes with the deeper groundwater in the pumped discharge.

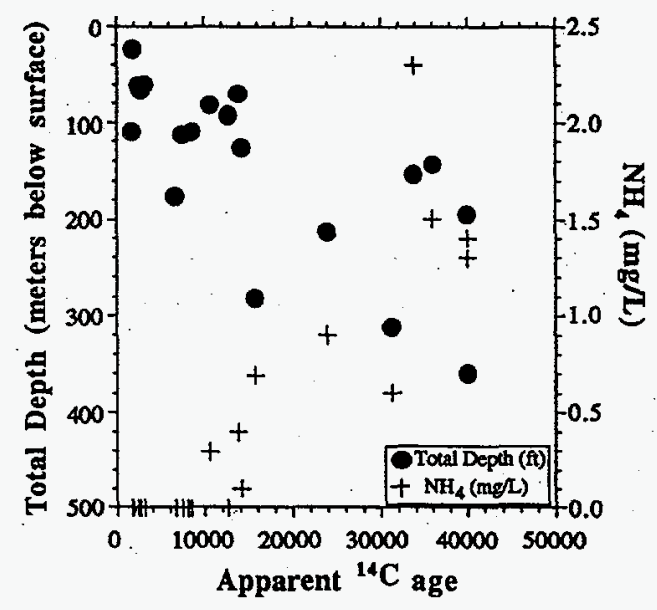

Figure 1. The apparent ${ }^{14} \mathrm{C}$ age of the Dakota groundwater increases with depth below the surface matched by increasing dissolved ammonium levels.

Groundwaters sampled from the Dakota show a total variation in $\delta^{18} \mathrm{O}$ values of approximately $5.5 \% \circ$ and $\delta \mathrm{D}$ of approximately $45 \%$, and all have a strong affinity to the Global Meteoric Water Line. The total variation reflects the observed stable isotope variation in average precipitation along an west-east transect from the eastern edge of the Colorado Front Range to the central portion of Kansas. The observed variations are attributed to temperature variations (elevation) in cloud condensation occurring over differing physiographic regions. Bomb-pulse ${ }^{3} \mathrm{H}$ occurs only in groundwaters with $\delta^{18} \mathrm{O}$ 
values approximately $-11.0 \%$ or higher. In addition, the ${ }^{3} \mathrm{H}$ occurs in wells with penetration depths of 100 meters or less, suggesting that the groundwater is derived in part from local recharge. These relations indicate that the locallyrecharged groundwaters infiltrating into the Dakota aquifer have $\delta^{18} \mathrm{O}$ values that reflect local meteoric water along the transect and differ from the lower $\delta^{18} \mathrm{O}$ values $(\leq-11 \% 0)$ observed in the western part of the transect and in the confined zones of central Kansas. The younger ${ }^{14} \mathrm{C}$ aged groundwater is $\geq-11.0 \%$ in $\delta^{18} \mathrm{O}$ and, as expected, is related to areas dominated by local flow systems (Fig. 2). Groundwater around $-14.0 \%$ (with apparent age $\sim 10,000$ yrs.) appears related to the intermediate-scale flow system recharged at higher elevations southwest of the transect, where meteoric water $\delta^{18} \mathrm{O}$ values are lower. The intermediate-scale flow mixes with higher 180 groundwater in local flow systems in the southwestern part of the transect. The intermediate-scale groundwater is also the predominant flow into the confined zone northeast of the Arkansas River, where the oldest

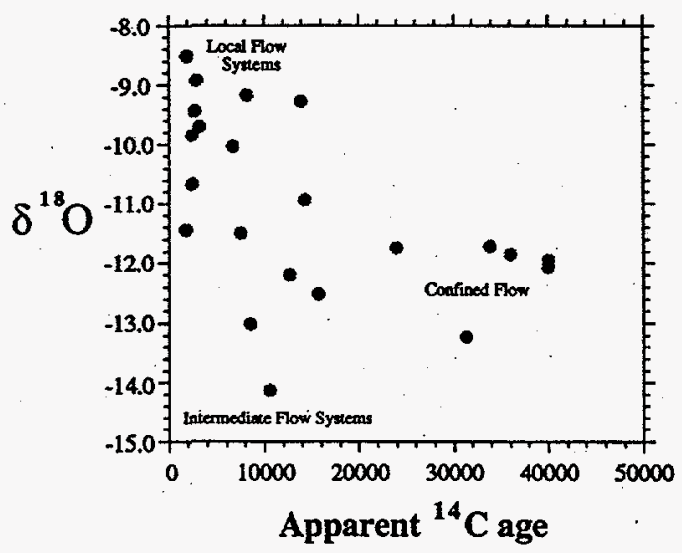

Figure 2. Mixing of the apparent ${ }^{14} \mathrm{C}$ ages and $\delta^{18} \mathrm{O}$ values of groundwater delineate the flow hierarchy in the Dakota aquifer.

apparent ${ }^{14} \mathrm{C}$ aged groundwater occurs that has a $\delta^{18} \mathrm{O}$ around $-12.0 \%$. The stable isotope and ${ }^{14} \mathrm{C}$ age variations are systematic and consistent with model predictions (Macfarlane, 1993) that the Dakota is dominated by local flow systems in southeastern Colorado that are distinct from the intermediate-scale flow system that underlies much of the study area.

The ${ }^{36} \mathrm{Cl} / \mathrm{Cl}$ ratios vary $>3$ orders of magnitude in the Dakota groundwaters. Southeastern Colorado groundwater has ${ }^{36} \mathrm{Cl} / \mathrm{Cl}$ ratios from 980 to $1500 \times 10^{-15}$, while western and central Kansas groundwater shows a systematic increase in chloride concentration from 17 to $1400 \mathrm{mg} / \mathrm{L}$ with a corresponding decrease in the ${ }^{36} \mathrm{Cl} / \mathrm{Cl}$ ratio (down to $1.4 \times 10^{-15}$ ). The ${ }^{36} \mathrm{Cl} / \mathrm{Cl}$ ratio is below the detection limit for the most saline groundwater indicating that the $\mathrm{Cl}$ is derived from ${ }^{36} \mathrm{Cl}$-depleted marine sources. This is consistent with previous interpretations (Macfarlane et al., 1992) that the central portion of the transect is predominantly confined flow and the groundwater progressively increases its chloride concentration from upward diffusion and advection of dissolved Permian halites. In the western portion of the transect, an order of magnitude variation exists in the $\mathrm{Cl}$ concentrations, but with no corresponding variation in the ${ }^{36} \mathrm{Cl} / \mathrm{Cl}$ ratios. This is probably due to different amounts of evaporative concentration of $\mathrm{Cl}$ during recharge that increases the $\mathrm{Cl}$ concentrations without changing the ${ }^{36} \mathrm{Cl} / \mathrm{Cl}$ ratio.

Funding for this work was performed under the auspices of the U.S. DOE by LLNL under contract No. W-7405-Eng-48.

\section{REFERENCES}

Macfarlane, P.A., Whittemore, D.O., Chu, T.M., Butler, J.J., Wade, A., Coleman, J., Doveton, J.H., Mitchell, J.E., Kay, S. (1992) The Dakota Aquifer Program: Annual Report, FY91. Kansas Geological Survey Open-File Report 92-1. 93 pg.

Macfarlane, P.A. (1993) The effect of topography relief and hydrostratigraphy on the upper part of the regional groundwater flow system in southeast Colorado and western and central Kansas, with emphasis on the Dakota aquifer. Unpublished Ph.D. Dissertation, University of Kansas, Lawrence Kansas. 197 pg. 
Published in Water and Energy Resources of the Dakota Aquifer: Workshop and Clinic, 1994, Great Bend, Kansas, Kansas Geological Survey and Kansas Ground Water Association, p. 15-16.

USING A COMBINED ISOTOPIC, MAJOR AND TRACE ELEMENT APPROACH TO DISCRIMINATE FLOW-SYSTEMS, WATER QUALITY AND GROUND. WATER AGES WITHIN THE DAKOTA AQUIFER, COLORADO THROUGH KANSAS

\author{
David K. SMITH, M. Lee DAVISSON, Nuclear Chemistry Division, Lawrence Livermore \\ National Laboratory, Livermore, CA 94550 \\ Donald O. WHITTEMORE, P. Allen MACFARLANE, Geohydrology Section, Kansas \\ Geological Survey, Lawrence, KS 66047 \\ Alan M. VOLPE, Sidney NIEMEYER, Jacqueline M. KENNEALLY, Bradley K. ESSER, \\ Nuclear Chemistry Division, Lawrence Livermore National Laboratory.
}

The Geohydrology Section of the Kansas Geological Survey and the Nuclear Chemistry Division of the Lawrence Livermore National Laboratory have conducted an isotopic, major and trace element investigation of ground waters produced from 20 supply wells along a 500 kilometer transect of the Dakota aquifer from southeastern Colorado through central Kansas. Our intent is to provide information on the flow characteristics, age and quality of ground waters in the Dakota aquifer which can ultimately be used by planning and governmental agencies concerned with best managing the ground water resources of the Great Plains. The Dakota aquifer is presently used for irrigation, public water supply and industry throughout portions of the western Kansas and eastern Colorado. Well yields in southwestern and central Kansas can exceed 2,000 gallons/minute. At present, pumping rates for the Dakota exceed recharge.

Ground water flow in the Dakota aquifer is from unconfined recharge areas in southeastern Colorado and southwestern Kansas to discharge areas in central Kansas. The aquifer is recharged by precipitation in unconfined outcrops in southeastern Colorado and central Kansas, and by freshwater infiltration from the overlying Ogallala aquifer in southeastern Colorado and southwestern Kansas. A confined flow system northeast of the Arkansas River is laterally recharged by water from the southwest which flows beneath the Arkansas River Valley. In central Kansas, saltwaters migrate upwards by diffusion and advection into the Dakota where confining layers pinch-out.

Our transect study of ground water chemistry in the Dakota aquifer emphasizes the validity of multiple element and isotope applications in resolving disparate waters that have mixed, discriminating waterrock and redox reactions within a complex hydrostratigraphy and establishing reliable chronometers to trace ground water flow. Isotopic and trace element discrimination of unique end-members is required to interpret ground water ages and the sources of recharge. Dissolved ${ }^{87} \mathrm{Sr} /{ }^{86} \mathrm{Sr},{ }^{36} \mathrm{Cl} / \mathrm{Cl},{ }^{14} \mathrm{C}$, stable isotopes, transition metal, alkali and alkaline earths, halogens and actinides supplemented by analysis of major cations and anions are measured in concert from a single sample. The combined approach is important because hydrologic relations within these aquifers are complex and interpretation based exclusively on one tracer is likely to be ambiguous; as well, the independent tracers and chronometers serve as cross checks on one another.

The hydrochemistry indicates a systematic modification of the ground water chemistry is controlled by the flow system hierarchy. Southwest of the Arkansas River, young ( $<15,000$ year apparent age) oxidized water is associated with shallower depths and unconfined local flow systems where

dissolved ${ }^{87} \mathrm{Sr} /{ }^{86} \mathrm{Sr}(0.7094-0.7088),{ }^{36} \mathrm{Cl} / \mathrm{Cl}\left(10-15 \times 10^{-13}\right), \mathrm{Cr}(0.01-0.3 \mu \mathrm{g} / \mathrm{L})$ and $\mathrm{U}(7-25$ $\mu \mathrm{g} / \mathrm{L})$ are relatively enriched. Northeast of the Arkansas River, older (15,000-40,000 year apparent age) and chemically reduced waters are associated with a confined, intermediate-scale flow systems within the Dakota aquifer; these waters are enriched in $\mathrm{HCO}_{3}^{-}(300-550 \mathrm{mg} / \mathrm{L}), \mathrm{NH}_{4}^{+}(0.5-1.8$ $\mathrm{mg} / \mathrm{L})$ and $\mathrm{Cl}^{-}(17-1400 \mathrm{mg} / \mathrm{L})$ and are depleted in elemental and radiogenic $\mathrm{Sr}(\mathrm{Sr}: 60-500 \mu \mathrm{g} / \mathrm{L}$, 
$\left.{ }^{87} \mathrm{Sr} / 86 \mathrm{Sr}: 0.7080-0.7086\right)$ and ${ }^{36} \mathrm{Cl} / \mathrm{Cl}\left(0.01-8.0 \times 10^{-13}\right)$.

Southwest of the Arkansas River, $\mathrm{HCO}_{3}$ - concentrations vary due to effects of soil processes on recharge and the distribution of $\mathrm{HCO}_{3}^{-}$sources in the aquifer. In general, $\mathrm{HCO}_{3}^{-}$content increases along the flow path from the unconfined recharge area to the confined portion of the aquifer; calcite dissolution and oxidation of organic matter are the primary sources of increased $\mathrm{HCO}_{3}^{-}$ concentrations. Evapotranspiration in the vadose zone affecting the recharge chemistry may drive an order of magnitude variation in $\mathrm{Cl}^{-}$concentration associated with a nearly constant ratio of $36 \mathrm{Cl} / \mathrm{Cl}$. Increasingly radiogenic ${ }^{87} \mathrm{Sr} /{ }^{86} \mathrm{Sr}$ ground water signatures are attributed to equilibration with albite or $\mathrm{K}$-feldspar in granitic basement or detrital clastic rocks derived from the Front Ranges in Colorado. Northeast of the Arkansas River Valley, lower ${ }^{87} \mathrm{Sr} / 86 \mathrm{Sr}$, higher $\mathrm{Cl} / \mathrm{Br}$ ratios $(1700-8500)$ and higher $\mathrm{Cl}^{-}$concentrations $(>30,000 \mathrm{mg} / \mathrm{L}$ ) are indicative of deeper Permian saltwaters derived from the dissolution of halite and anhydrite that migrate upwards by diffusion and discharge into the base of the Dakota in central Kansas. A decrease in ${ }^{36} \mathrm{CV} / \mathrm{Cl}$ ratio is the result of increasing chloride concentrations which lowers the ratio. Ion-exchange on clays decreases $\mathrm{Ca}, \mathrm{Sr}$ and $\mathrm{Ba}$ abundances. A ${ }^{87} \mathrm{Sr} / 86 \mathrm{Sr}$ and $\mathrm{Sr}$ concentration variation diagram illustrates mixing between the meteoric and saline end-members. Multi-valent trace element $\left(\mathrm{Cr}^{+6}\right.$ and $\left.\mathrm{U}^{+6}\right)$ concentrations of Dakota ground waters increase at both ends of the transect and track oxidizing ground waters within the unconfined portions of the aquifer. In the confined segment, more reducing conditions prevail as indicated by lower $\mathrm{Cr}$ and $\mathrm{U}$ and higher $\mathrm{NH}_{4}{ }^{+}$concentrations.

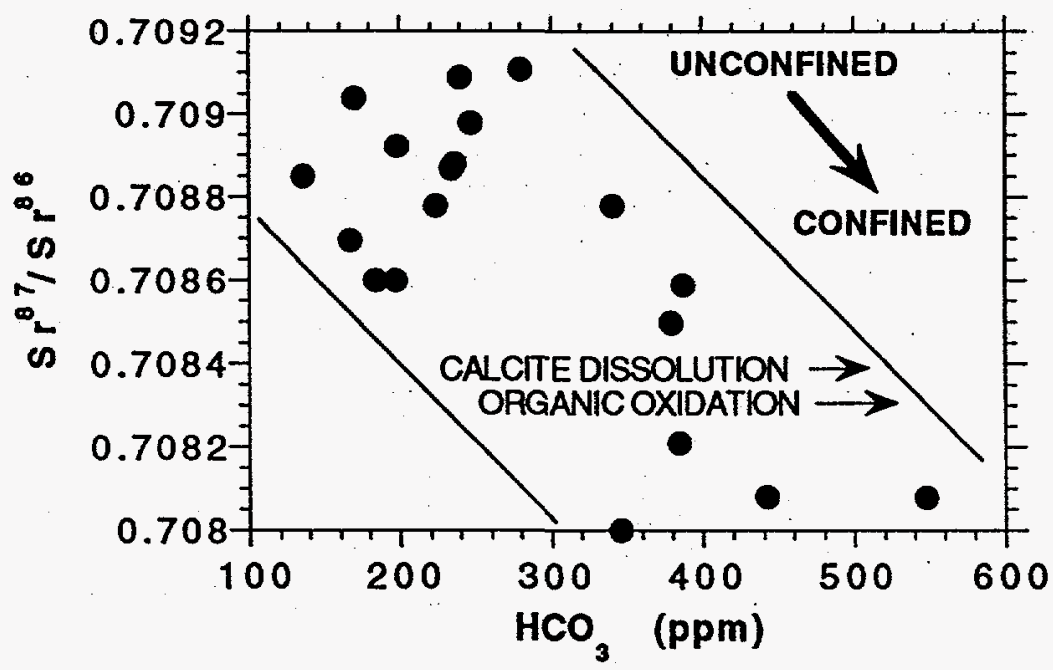

$\mathrm{Sr}^{87} / \mathrm{Sr}^{86}$ verses $\mathrm{HCO}_{3}$ - for the Dakota aquifer; bicarbonate concentration increases along the flow-path.

Analysis of major and trace elements and isotopic ratios in Dakota ground waters provides information on recharge mechanisms, flow rates and water quality. Localized and intermediate scale flow-systems and flow rates can be identified using isotopic and elemental fingerprints unique to each; additionally, the source of dissolved solids affecting potable waters may be similarly determined. Thorough understanding of ground water flow-systems, ages and quality is imperative to manage water supplies for public, industrial and agricultural constituencies throughout eastern Colorado and western and central Kansas.

Work performed under the auspices of the U.S. Department of Energy by Lawrence Livermore National Laboratory under Contract W-7405-Eng-48. 
COMBINED USE OF ${ }^{14} \mathrm{C}$ AND STABLE ISOTOPES TO MAP AND MODEL GROUNDWATER SYSTEMS

DAVISSON. M. L and VELSKO, C.A., Lawrence Livermore Lab L-237, Livermore CA 94550, USA, CRISS, R. E., and CAMPBELL, K.R., Geology Depart., University of California, Davis, CA 95616, MACFARLANE, P.A., Kansas Geological Survey, Lawrence, KS. 66047

AMS techniques make available abundant and detailed ${ }^{14} \mathrm{C}$ measurements that, when coupled with stable isotope data, can define spatial images, apparent ages, and fluxes in hydrologic systems at different scales. A new extraction technique routinely utilizes $35 \mathrm{ml}$ water samples that require only simple field sampling methods, making ${ }^{14} \mathrm{C}$ analyses for hydrologic samples straight forward and convenient. Such easy access of these data make possible generation of detailed quantitative models of groundwater systems or validation of previously derived groundwater models. For example, groundwater beneath the City of Sacramento, California $\left(100 \mathrm{~km}^{2}\right)$ has two large groundwater cones of depression ( $30 \mathrm{~m}$ below sea level) that are reflected by $18 \mathrm{O}$ variations. Progressive groundwater depletion causes ancient (to $16 \mathrm{ka}$ ) groundwater beneath the city to be replaced by recharged modern American and Sacramento River waters $\left(\delta^{18} \mathrm{O}=-11.0\right.$, and ${ }^{14} \mathrm{C}=>100 \%$ modern carbon) into the aquifer at a rate of $-5 \%$ of the annual groundwater consumption. Lateral groundwater flow rates adjacent to the rivers calculated from the $\delta^{18} \mathrm{O}$ isopleths are $30-60 \mathrm{~m} / \mathrm{yr}$, where vertical flow rates calculated from downward migration of bomb-pulse ${ }^{14} \mathrm{C}$ is about one order of magnitude lower. These same rates are observed in other parts of the southern Sacramento Valley, where groundwater cycling from intensive agricultural irrigation is calculated to be six times greater than the natural groundwater flow rates and have led to degradation of the water quality.

As another example, large scale (450 km x-section) ${ }^{14} \mathrm{C}$ and stable isotope characterization of groundwater systems in the Great Plains regions differentiates groundwater of young local-flow systems from older intermediate-scale flow systems. Local flow systems dominate areas of hill and valley-type topography, where apparent ages vary between $2-15 \mathrm{ka}$ and the $\delta^{18} \mathrm{O}$ values $(-8.5$ to $-11.5 \% \%)$ reflect local recharge. Intermediate-scale flow systems vary between 10 to $>40 \mathrm{ka}$ and have $\delta 18 \mathrm{O}$ values $(-11.5$ to $-14.0 \%$ ) that reflect recharge from higher elevations just east of the Front Range of Colorado. These data are used to validate and calibrate a previously derived finite difference model.

Funding for this work was performed under the auspices of the U.S. DOE by LiNL under contract No. W-7405Eng-48.

Published in Abstracts of the Eighth International Conference on Geochronology, Cosmoschronology and Isotope Geology (ICOG 8), 1994, U.S. Geological Survey Circular 1107, M.A. Lanphere, G.B. Dalrymple and B.D. Turrin (eds.), p. 296. 
Published in Abstracts of the Eighth International Conference on Geochronology, Cosmoschronology and Isotope Geology (ICOG 8), 1994, U.S. Geological Survey Circular 1107, M.A. Lanphere, G.B. Dalrymple and B.D. Turrin (eds.), p. 296.

\section{A COMBINED ISOTOPIC AND TRACE ELEMENT APPROACH TO DISCRIMINATING GROUNDWATER FLOW-PATHS}

SMITH, David K., DAVISSON, M.L., VOLPE, A.M., Nuclear Chemistry Division, Lawrence Livermore National Laboratory, Livermore, CA 94550; WHITTEMORE, D.O., MACFARLANE, P.A., Kansas Geological Survey, Lawrence, KS 66047; NIEMEYER, S., KENNEALLY, J.M., BEIRIGER, J.M., Lawrence Livermore National Laboratory

Regional studies of groundwater flow at the Nevada Test Site (NTS) and in the Dakota Aquifer in western and central Kansas emphasize the validity of multiple element and isotope applications in resolving disparate waters that have mixed, discriminating waterrock and redox reactions within a complex hydrostratigraphy and establishing reliable chronometers to trace groundwater flow. Isotopic and trace element discrimination of unique end-members is required to interpret groundwater ages and the sources of recharge. Dissolved ${ }^{87} \mathrm{Sr} / 86 \mathrm{Sr},{ }^{36} \mathrm{Cl} / \mathrm{Cl},{ }^{14} \mathrm{C}$, REE, transition metal, alkali and alkaline earths, halogens and actinides supplemented by analysis of major cations and anions are measured in concert from a single sample. The combined approach is important because hydrologic relations within these aquifers are complex and interpretation based exclusively on one tracer is likely to be ambiguous; as well, the independent tracers and chronometers serve as cross checks on one another.

At NTS, older ( $>40,000$ year apparent age) groundwaters produced from the regional Paleozoic carbonate aquifer are enriched in ${ }^{87} \mathrm{Sr} / 86 \mathrm{Sr}(0.7140-0.7150), \mathrm{Sr}(600-800 \mu \mathrm{g} / \mathrm{L})$ and $\mathrm{HCO}_{3}{ }^{-}(400-500 \mathrm{mg} / \mathrm{L})$ and depleted in $36 \mathrm{Cl} / \mathrm{Cl}\left(1-3 \times 10^{-13}\right)$ relative to younger $(<20,000$ year apparent age) waters derived from overlying Tertiary volcanic and volcaniclastic alluvial aquifers. Higher bicarbonate concentrations track.proportional increases in elemental and radiogenic Sr apparently derived from dissolution of Paleozoic carbonates. Lower ${ }^{36} \mathrm{Cl} / \mathrm{Cl}$ ratios for the carbonate waters confirms the presence of a "dead" chloride source in the Paleozoic rocks. The dissolution of Paleozoic carbonates has a major influence on the resulting ${ }^{14} \mathrm{C}$ atom abundance in groundwater and age correction models. REE analyses of NTS spring waters are controlled both by Eh and host rock signature. Spring waters discharging from silicic Tertiary aquifers yield evolved, fractionated chondrite normalized patterns in contrast to spring waters in possible connection with the regional Paleozoic aquifer which exhibit flat chondrite normalized REE patterns and negative $\mathrm{Ce}$ and no Eu anomalies.

In Kansas, isotopic and elemental analysis of shallow groundwater collected along a $500 \mathrm{~km}$ transect of the Dakota aquifer from southeastern Colorado to central Kansas indicates that a systematic modification of the groundwater chemistry is controlled by the flow system. Southwest of the Arkansas River, young $(<15,000$ year apparent age) oxidized water is associated with shallower depths and unconfined local flow systems where dissolved ${ }^{87} \mathrm{Sr} / 86 \mathrm{Sr}(0.7094-0.7088), 36 \mathrm{Cl} / \mathrm{Cl}\left(10-15 \times 10^{-13}\right), \mathrm{Cr}(0.01-0.3$ $\mu \mathrm{g} / \mathrm{L})$ and $\mathrm{U}(7-25 \mu \mathrm{g} / \mathrm{L})$ are relatively enriched. Northeast of the Arkansas River, older (15,000-40,000 year apparent age) and chemically reduced waters are associated with a confined, intermediate-scale flow systems within the Dakota aquifer; these waters are enriched in $\mathrm{HCO}_{3}^{-}(300-550 \mathrm{mg} / \mathrm{L}), \mathrm{NH}_{4}(0.5-1.8 \mathrm{mg} / \mathrm{L})$ and $\mathrm{Cl}^{-}(17-1400 \mathrm{mg} / \mathrm{L})$ and are depleted in elemental and radiogenic $\mathrm{Sr}\left(\mathrm{Sr}: 60-500 \mu \mathrm{g} / \mathrm{L},{ }^{87} \mathrm{Sr} / 86 \mathrm{Sr}: 0.7080-0.7086\right)$ and $36 \mathrm{Cl} / \mathrm{Cl}\left(0.01-8.0 \times 10^{-13}\right)$. Ion exchange and carbonate equilibria are major controls on 
$\mathrm{Sr}$ and $\mathrm{HCO}_{3}$ - concentrations respectively. The confined flow system is laterally recharged by water from the southwest which flows beneath the Arkansas River Valley; lower ${ }^{87} \mathrm{Sr} / 86 \mathrm{Sr}$ and higher $\mathrm{Cl} / \mathrm{Br}$ ratios $(1700-8500)$ are indicative of deeper Permian saltwaters that migrate upwards by diffusion and discharge into the base of the Dakota aquifer.

Work performed under the auspices of the U.S. Department of Energy by the Lawrence Livermore National Laboratory under Contract W-7405-Eng-48. 